Click www.researchjournal.co.in/online/subdetail.html to purchase.

Volume 5 | Issue 2 | September, 2014 | 139-142 $\mathbf{a}$ e ISSN-2231-6434 |

International Research Journal of Agricultural Economics and Statistics

Visit Us - www.researchjournal.co.in DOI : 10.15740/HAS/RJAES/5.2/139-142

\title{
Research Paper Economics production of vegetables in Belgaum district in Karnataka
}

\section{SAMEER LOKAPUR AND G.N. KULKARNI}

ABSTRACT: The study aimed to analyze cost and returns structure of major vegetables in the Belgaum district which has high concentration of area under vegetables. The multi-stage random sampling procedure was adopted to choose the 120 sample farmers. The study revealed that the average per hectare utilization of human labour was the highest in case of potato farms (78.77 man days) followed by onion farmers (70.25 man days), tomato farmers ( 66.37 man days) and green chilli farmers (48.13 man days). The total cost incurred by farmers on potato cultivation was high cost (Rs. 47299.86/ha) as compared to onion (Rs. 31240.2/ha), green chilli (Rs. 25797.37/ ha), and tomato (Rs. 27532.42/ha). The high cost in potato was attributed high seed rate. The gross returns was also highest in case of potato (Rs.130410.60/ha) followed by onion (Rs.124518.60/ha), tomato (Rs.64969.70/ ha), and chilli (Rs.55250.00/ha). The net returns were highest in case of onion (Rs.93278.43/ha) and lowest in case of green chilli (Rs.29452.63/ha). The study indicated that cultivation of vegetables was found to be profitable as indicated by net returns and high $\mathrm{B}: \mathrm{C}$ ratios.

KEY WORDS : Production and economics, Vegetables, Seed rate, Human labour

HOW TO CITE THIS PAPER : Lokapur, Sameer and Kulkarni, G.N. (2014). Economic production of vegetables in Belgaum district in Karnataka. Internat. Res. J. Agric. Eco. \& Stat., 5 (2) : 139-142. 